\title{
Adaptation behavior of Bornean Orangutan (Pongo pygmaeus morio) reintroduction in Kehje Sewen Forest, East Kalimantan, Indonesia
}

\author{
SYAHIK NUR BANI ${ }^{1,2, \bullet}$, DYAH PERWITASARI-FARAJALLAH ${ }^{1,3, \bullet \bullet}$, SRI SUCI UTAMI ATMOKO ${ }^{2,4}$, \\ JAMARTIN SIHITE 5 \\ ${ }^{1}$ Department of Biology, Faculty of Mathematic and Natural Sciences, Institut Pertanian Bogor. Jl. Agatis, Darmaga, Bogor 16680, West Java, Indonesia \\ Tel./fax.: +62-251-8622833, "email: syahik23@gmail.com,"vwitafar@ipb.ac.id \\ ${ }^{2}$ Primate Research Center, Universitas Nasional. Jl. Sawomanila, South Jakarta 12520, Jakarta, Indonesia \\ Primate Research Center, Institut Pertanian Bogor. Jl. Agatis, Darmaga, Bogor 16680, West Java, Indonesia \\ ${ }^{4}$ Faculty of Biology, Universitas Nasional. Jl. Sawomanila, South Jakarta 12520, Jakarta, Indonesia \\ ${ }^{5}$ Borneo Orangutan Survival Foundation (BOSF). Jl. Kumbang No. 31, Bogor 16128, West Java, Indonesia
}

Manuscript received: 5 September 2017. Revision accepted: 7 May 2018

\begin{abstract}
Bani SN, Perwitasari-Farajallah D, Atmoko SSU, Sihite J. 2018. Adaptation behavior of Bornean Orangutan (Pongo pygmaeus morio) reintroduction in Kehje Sewen Forest, East Kalimantan, Indonesia. Biodiversitas 19: 989-996. Bornean Orangutan (Pongo pygmaeus) are grouped into three subspecies, including Pongo pygmaeus morio that spreads from Sabah to the southern parts of Mahakam River in East Kalimantan. Forest conversion is the main threat to the populations and habitat of Bornean orangutans. The orangutans which have been confiscated are going through rehabilitation process and reintroduction. Efforts should be taken to seize or confiscate orangutans as much as possible and return them to their natural forest habitat. This research aimed: (i) to measure the development of rehabilitated orangutans in their post-release adaptation in native forest, especially in activity budget, diet, nesting and strata usage, in comparison to wild orangutans in the Danum Valley, (ii) to identify factors determining successful reintroduction of orangutans based on their final stage in rehabilitation process. Daily activities of four adult females of the orangutan with different types of last stage rehabilitation processes (pre-release island vs. cages) were compared during the monitoring of their behavior one year after their release in Kehje Sewen forest using focal animal sampling method. The analysis showed that diet pattern of all individuals resembled that of their wild orangutan counterparts. Meanwhile, activity pattern, strata usage, and nesting behavior was related to individual's capabilities and not determined by the type of final stage in the rehabilitation process. We assumed other factors should be considered as success factors of reintroduction.
\end{abstract}

Keywords: Activity budget, diet, nesting, orangutan, reintroduction, strata usage

\section{INTRODUCTION}

Orangutans are the only great apes that previously spread in South Asia to Southeast Asia (Delgado and van Schaik 2000) but now are only found in Borneo and Sumatra Islands (Groves 2001). Since last year there are three recognized orangutan species, i.e., Sumatran orangutan (Pongo abelii), Tapanuli orangutan (Pongo tapanuliensis) and Bornean orangutan (Pongo pygmaeus) (Nater et al. 2017). Bornean orangutan (P. pygmaeus) are grouped into three subspecies, including $P$. pygmaeus morio that spreads from Sabah to the southern parts of Mahakam River in East Kalimantan, Indonesia.

Orangutans are primarily frugivorous; they prefer fruit as their staple food (Utami et al. 1997; Russon et al. 2009). Distribution of plants strongly influences the length and extent of an adult orangutan's roaming area. According to Utami-Atmoko et al. (2009), the range of adult male orangutan can reach 1,000-1,500 ha, and that of adult females is about 250-300 ha. Female orangutans tend to be philopatric; they settle in or close to the area where they were born (Singleton et al. 2009; van Noordwijk et al. 2012).
Forest conversion is the main threat to the habitat and populations of Bornean orangutans (Soehartono et al. 2007). This causes many individual orangutans to die or be captured by the community. Based on the IUCN Best Practice Guideline for the reintroduction of Great Apes (Baker 2002; Beck et al. 2007), the orangutan that has been saved and confiscated must be rehabilitated, and reintroduction efforts to their natural habitat should be made as soon as possible.

Rehabilitation is a process where an animal receives physical and health care from humans until it becomes healthy again. This process also aims to help the animal to learn social behavior and ecological capabilities needed for their eventual. In rehabilitation, orangutans have limited contact with humans to eliminate their dependence on humans and enable them to survive independently in their wild habitat (Beck et al. 2007).

Orangutans arriving at the rehabilitation center will undergo several processes: (i) medical examinations to determine the age and illness (Beck et al. 2007), (ii) orangutans will develop the ability to survive in the forest through the forest school. Orangutans will also be introduced with the kinds of natural food and be required to make a nest in a tree (Russon 2002; Russon et al. 2007), 
(iii) orangutans will learn to move in the trees to avoid the threat of predators, namely pigs and clouded leopard (Jule et al. 2008) and parasites on the ground (Grundmann et al. 2006). The rehabilitants orangutans are ready to be released to the wild. The ideal age of an orangutan for reintroduction ranges from 7-8 years, as the orangutan is expected to be more active and skillful in finding food at this age (Russon 2006).

Reintroduction is a wildlife conservation effort by returning the animal to its natural habitat (Beck et al. 2007). Reintroduction is also the fastest tool to address the decline in population numbers in the wild (Russon 2009). One way to see the success of reintroduction is by monitoring post-release daily activities (Russon 2009), including feeding behavior and other activities such as day range (Yeager 1997; Grundmann 2006). This study is critical because data about the success of Bornean orangutan release is currently still very limited, especially those associated with the final stage of the rehabilitation process.

Kehje Sewen Ecosystem Restoration Forest in East Kalimantan is an area of forest ecosystem restoration (IUPHHK-RE) in East Kalimantan Province. IUPHHK-RE can provide a safe and permanent place for free rehabilitant orangutans to build new wild orangutan populations. The Restoration of Orangutan Habitat Indonesia (RHOI) has released 75 individuals of orangutans at Kehje Sewen Forest Camps since 2012. Post-release monitoring is necessary to determine the adaptation of each orangutan to new habitat conditions. $\square$

This research aimed: (i) to measure the rehabilitated orangutan`s development after their post-release adaptation in natural forest, (ii) to identify success factors of reintroduction based on the final stage type of rehabilitation process (island and cage). The result will be an overview of post-release monitoring in adult (aged 15-20 years ) female orangutans. $\square$

\section{MATERIALS AND METHODS}

\section{Study site}

This research was conducted during July to September 2014, one-year post-release in the Kehje Sewen Ecosystem Restoration Forest, ( $1^{\circ} 66^{\prime} 36^{\prime \prime} \mathrm{LU}-1^{\circ} 40^{\prime} 48^{\prime \prime} \mathrm{LU} ; 116^{\circ} 1^{\prime} 12^{\prime \prime}$ BT-116 $28^{\prime} 12^{\prime \prime}$ BT). Kehje Sewen Ecosystem Restoration Forest (IUPHHK-RE) - Ex-Mugitriman study site is located in East Kalimantan and roughly 86,450 Ha in size, inside a former area of HPH PT. Mugitriman Intercontinental is located in the Sub-district of Muara Wahau, District of East Kutai, East Kalimantan, Indonesia $\pm 500 \mathrm{~km}$ from Samarinda City (Figure 1). Kehje Sewen Ecosystem Restoration Forest has been disturbed by logging activity, but a survey in 2008 found that 482 tree species, 229 birds, 53 mammals, 24 amphibians and 15 reptiles species remained. There is still a high abundance of orangutan food species (at least 104 tree species, 13 liana species, 22 rattan species.

\section{Research object}

This study focused on four individual orangutans and the background type of final stage rehabilitation process (Table 1). Sarmi and Siwi were individual females of semiwild orangutans who went through the forest school process and pre-release on the artificial island (Island 6, 2 ha) in Samboja Lestari Rehabilitation Center. Furthermore, Wani and Leke were individual females of ex-captive (confiscated) orangutans who went through the process after the forest school, they returned (social cage, $10 \mathrm{~m}^{2}$ ) for seven years without any pre-release stages. $\square$

The artificial island at the Samboja Lestari Rehabilitation Center is a human-made island (including vegetation and enrichment) used as pre-release area. It is surrounded by a large ditch full of water barrier and supported with food two times per day. The cage is a building made of iron.

The island is an area of natural forest rehabilitation with minimum support from humans, while the cage is a houselike building made of iron. Both places serve to hold the orangutans until being released to nature. We recorded the behavior of focal orangutans by Focal Animal Sampling instantaneously sampled with a sample interval of $2 \mathrm{~min}$ (Altman, 1974) and Ad Libitum that recorded all activities outside the time interval.

We assessed daily activities by recording feeding, moving, and resting. Whenever feeding occurred, we recorded the food item consumed: fruit, leaf, cambium, insect, and others: stem, pith, flower, soil, water. To calculate the activity budgets and for comparison with data from wild orangutans, we excluded the time spent feeding on provisions. To evaluate nest-building abilities, we counted all nests that were reused or newly built by each individual (day and night nests). The rebuilding of already existing nests occurred only three times during the observation period, and we, therefore, did not include it in the analysis. $\square$

Tabel 1. Individual, sex, age, origin, final stage of rehabilitation, time of release, start observation, and total observation hours

\begin{tabular}{|c|c|c|c|c|c|c|c|}
\hline Individual & Sex & Age & Final stage of rehabilitation & Origin & $\begin{array}{l}\text { Time of } \\
\text { release }\end{array}$ & $\begin{array}{c}\text { Start } \\
\text { of observation }\end{array}$ & $\begin{array}{c}\text { Total } \\
\text { observation } \\
\text { hours }\end{array}$ \\
\hline Siwi & Female & $15 \mathrm{yr}$ & Four years $\square$ artificial island & Semi-wild & $13 / 10 / 2013$ & 07/07/2014 & 70 hours \\
\hline Sarmi & Female & $19 \mathrm{yr}$ & Four years $\square$ artificial island & Semi-wild & $13 / 10 / 2013$ & $14 / 09 / 2014$ & 28 hours \\
\hline Mona & Female & $20 \mathrm{yr}$ & Seven years cage $\square$ & Ex-captive & $13 / 10 / 2013$ & $02 / 09 / 2014$ & 84 hours \\
\hline Inge & Female & $15 \mathrm{yr}$ & Six years cage $\square$ & Ex-captive & $13 / 10 / 2013$ & 07/07/2014 & 42 hours \\
\hline
\end{tabular}




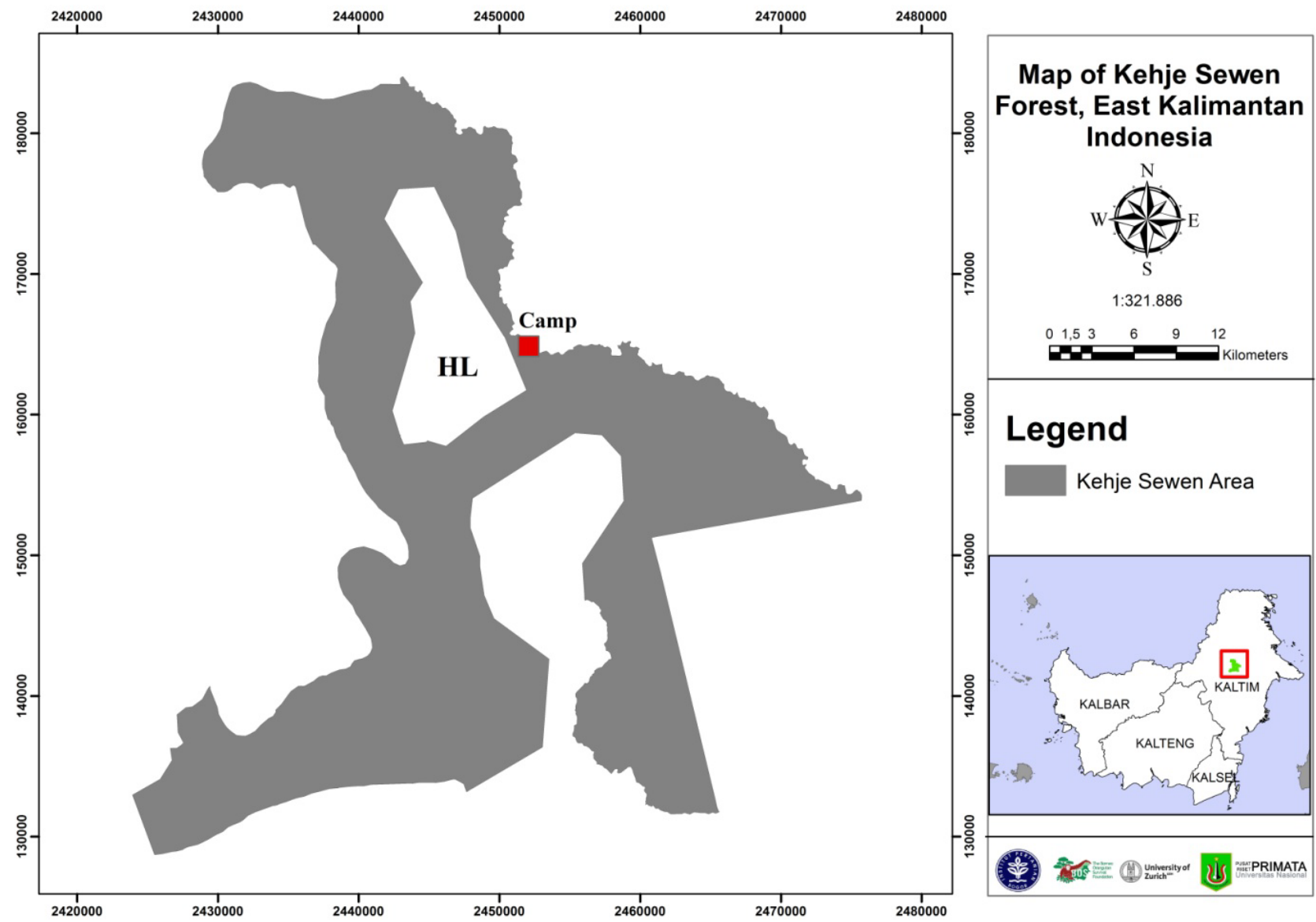

Figure 1. Map of Kehje Sewen forest, East Kalimantan, Indonesia

We also estimated the focal orangutan's vertical position in the canopy every $2 \mathrm{~min}$. To simplify recording, we used intervals of $5 \mathrm{~m}(<1$ : location on the ground or some substrate lying on the ground; $1+$ : location between 1 $\mathrm{m}$ and $4.99 \mathrm{~m}$; 5+: location between $5 \mathrm{~m}$ and $9.99 \mathrm{~m}$; etc.). For comparability with other studies, we used standardized published online (Morrogh-Bernard et al. 2002; van Schaik and van Noordwijk 2003). We also assessed the home range, started from the nest in the morning until the individual made a nest for sleeping in the early evening.

\section{Data analysis}

Reintroduction success factor was measured based on the data as the daily observation periods differed, depending on the time the orangutans were active in the forest. We calculated the time spent in each behavioral category (foraging, moving, resting, etc.) as a percentage of daily activity time in the forest. To analyze foraging behavior in more detail, we calculated the time individuals fed on the different food items as a percentage of individual foraging time in the forest. To evaluate learning trends of the individual orangutan, we investigated changes in food choice and height use.

We compared the individual rates (\%) of time spent consuming different food items and the individual rates (\%) of time spent at different heights. To compare activity budgets with those of wild conspecifics, we used data from Danum Valey (Sabah) (Kanamori et al. 2010), low land a mixed dipterocarp forest and the most suitable habitat on Borneo for comparison. We compared our results to those of sexually active females because these age classes were the closest in age to the studied orangutans. We applied nonparametric tests [Mann-Whitney U (MWU) tests] for independent samples. Significance was set to a level of $\mathrm{p} \leq 0.05,2$-tailed. Mapping and counting of the home range were conducted by using GIS Arc View 3.3 software.

\section{RESULTS AND DISCUSSION}

\section{Daily activities}

The daily activity of reintroduction orangutans in Kehje Sewen forest is presented in Figure 2. The daily activity pattern of orangutans depends on the capacity of each individual orangutan after one year of release. The four female orangutan individuals that went through the final stages of different rehabilitation processes showed significant differences between Sarmi and Siwi (semi-wild, artificial islands). The daily activities pattern of Sarmi followed the wild orangutan behavioral pattern. The most significant activity was feeding (57\%), followed by resting $(24.04 \%)$. While Siwi's most significant activity was 
resting (64.67\%) (Mwu-test: $\mathrm{p}<0.046)$ (Table 2). Meanwhile, the pattern of Mona orangutan individual's behavioral activity (ex-rehab, cage) tended to be high in resting $(58.86 \%)$

Mona and Siwi spent most of their time resting since they were less exploring the surrounding environment, especially in the location of food sources. This caused most of the individuals to dwell and observe the surrounding area. Meanwhile, Inge (ex-rehab, cage) followed the wild orangutan behavior pattern. i.e., spending most of her activity for feeding $(62.05 \%)$, followed by resting $(19.52 \%)$. Wild orangutans in the Danum valley have an activity pattern of $47 \%$ feeding, $34 \%$ resting and $17 \%$ moving (Kanamori et al. 2010).

\section{Diet}

Food utilization of the four orangutans was similar in pattern, i.e., the fruits were the most consumed food (64.54-88.62\%), followed by young leaves, insects, and other types of feed (umbut, pith, flower, soil, water) (Figure 3). This finding is essential information for the variations of the diet of the released orangutan. Fruit was the type of food mostly consumed by wild orangutans in the Danum Valley compared to other kinds of food (Kanamori et al. 2010). Types of orangutan food plants from all orangutan research stations in Sumatra and Borneo comprised of 1,693 food plant species, including wild mangosteen (Garcinia sp.), wild rambutan (Nephelium sp.), Langsat (Baccaurea tetrandra), and also 16 species of invertebrates, 4 types of vertebrates, and 7 food types of other sources (Russon et al. 2009).

Table 2. The result of Mann Whitney test in the daily activity of orangutan in Kehje Sewen forest, East Kalimantan, Indonesia

\begin{tabular}{llll}
\hline Individual & Feeding & Resting & Moving \\
\hline $\begin{array}{l}\text { Siwi } \\
\text { Sarmi }\end{array}$ & $\mathrm{p}=0.739>0.05$ & $\mathrm{p}=0.046<0.05$ & $\mathrm{p}=0.867>0.05$ \\
$\begin{array}{l}\text { Mona } \\
\text { Inge }\end{array}$ & $\mathrm{p}=0.014<0.05$ & $\mathrm{p}=0.014<0.05$ & $\mathrm{p}=0.307>0.05$ \\
\hline
\end{tabular}

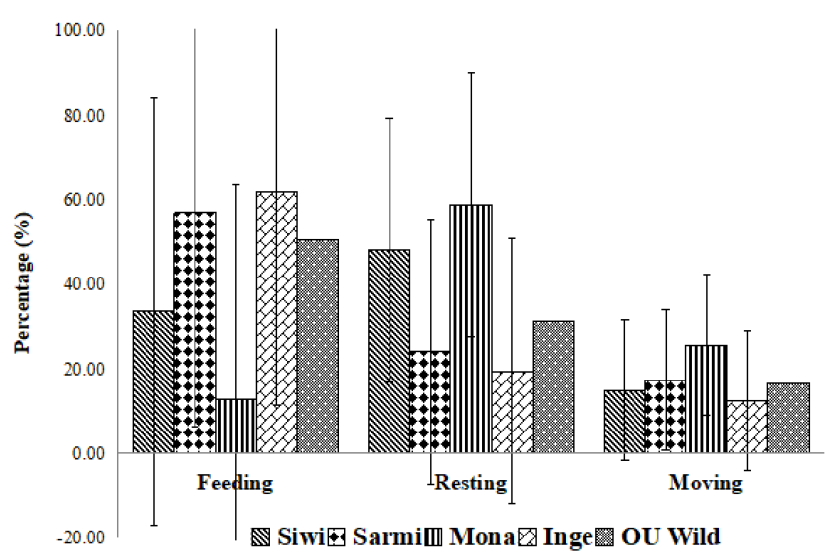

Figure 2. The proportion of daily activity of orangutan in Kehje Sewen forest, East Kalimantan, Indonesia
Fruit was the type of food most consumed by these reintroduced orangutans, which accounted for $64 \%$ followed by other types of food, e.g., 10.5-12.5\% young leaves. The fruits consumed by the four orangutans were from 25 species of plants. The plant consisted of lower plants, Liana, Palmae, and Zingiberaceae. All of the orangutan in this study primarily consumed fruit, and one individual Inge, consumed fruit more than often than wild orangutans in Danum Valley. $\square$

In addition to fruit, the other types of food mostly consumed was young leaves, especially by orangutan individual Sarmi who consumed young leaves entirely without removing the undesirable portions. In contrast to the way Sarmi consumed the young leaves; she consumed the old leaves by removing and dumping the unwanted parts. Thus, when the young leaves are small, the feeding behavior of adult females will change by looking for other alternative foods that are high in protein content such as insects and other categories (Morrogh-Bernard et al. 2009). The released orangutans used insects and other types of feed, as part of their adaptation strategy to survive and succeed in their natural habitat. $\square$

In addition to the young leaves, the orangutan individuals Sarmi and Mona also utilized the cambium and insects on their feeding activity (Mwu-test: $p<0.014$ ) (Table 3). In adult females, the reproductive status affected the selection of food by preferring insects, vegetation, and other categories that are essential to provide nutritional needs that cannot be supplied by bark and other food categories (Delgado and van Schaik 2000; van Schaik 2006). The consumption of insects, vegetation, and other food categories by orangutan Sarmi was the highest as compared to other females because Sarmi ate ants every day. This is possible because of the abundant availability of insects and other types of feed that are unaffected by the seasons, making it a valuable alternative food source for the released orangutans when fruits are limitedly available.

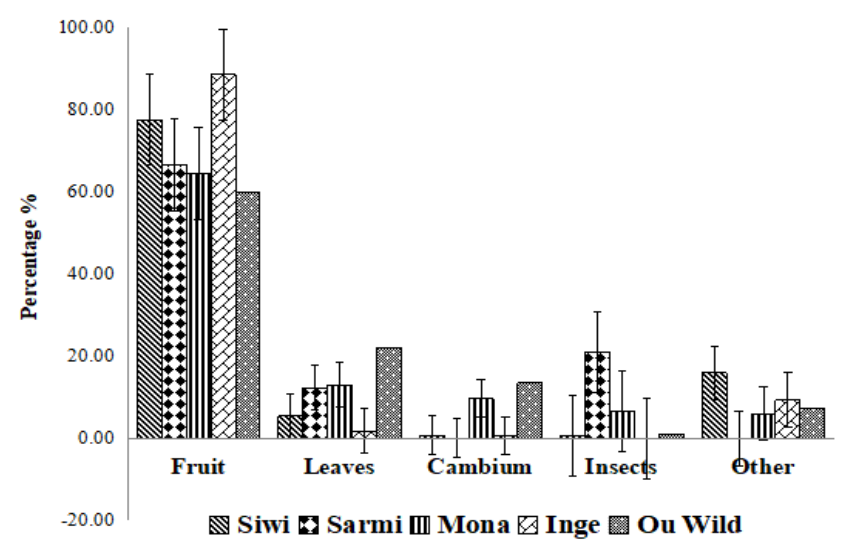

Figure 3. The proportion of orangutan diet in Kehje Sewen forest, East Kalimantan, Indonesia. 
Table 3. The results of Mann Whitney test in orangutan diet in Kehje Sewen forest, East Kalimantan, Indonesia.

\begin{tabular}{llllll}
\hline Individual & Fruit & Leaves & Cambium & Insects & Other \\
\hline $\begin{array}{l}\text { Siwi } \\
\text { Sarmi }\end{array}$ & $\mathrm{p}=0.505>0.05$ & $\mathrm{p}=0.814>0.05$ & - & $\mathrm{p}=0.317>0.05$ & - \\
$\begin{array}{l}\text { Mona } \\
\text { Inge }\end{array}$ & $\mathrm{p}=0.014<0.05$ & $\mathrm{p}=0.918>0.05$ & $\mathrm{p}=1.000>0.05$ & $\mathrm{p}=0.361>0.05$ & $\mathrm{p}=0.012<0.05$ \\
\hline
\end{tabular}

\section{Nesting}

Nesting behavior depends on the ability of each individual orangutan. All the four orangutan individuals had the same pattern of making new nests every day. Like other great apes in Africa (gorillas, bonobos, and chimpanzees), orangutans make sleeping nests on a daily basis in different locations (Prasetyo et al. 2009). Generally, the four females built a new nest, but it was also observed that Siwi used a repaired nest (Figure 4). However, Mona was found to reuse the old nest and not make a new nest as much as $30 \%$ of the time. Orangutans tended to make a stable nest of wind and avoid contact and conflict with humans. In forest schools (during the rehabilitation process), orangutans learned to live independently in the forest, ranging from feeding themselves to nesting on trees at night to avoid the threat of predators and social interaction with other orangutan individuals (Grundmann 2006).

\section{Strata used}

Another parameter used to determine the success of adaptation is the ability to move on a tree. Generally, the use of altitude on the four individual female orangutans ranged from the ground level $(0 \mathrm{~m})$ to $>10 \mathrm{~m}$ (Figure 5). The most frequently used elevations by Sarmi and Inge individuals was at altitudes of $>10 \mathrm{~m}$, while that for Siwi and Mona was 0 to $5 \mathrm{~m}$ ( $<<0.001$; Mwu-test) (Table 4). Most of the released orangutans used altitudes of above 10 $\mathrm{m}$, which was supported by the availability of fruits and other types of feed at these altitudes. Individual orangutans Sarmi and Inge sometimes went down from the trees $(0-5$ $\mathrm{m})$ to consume pith and terrestrial insects or to drink water from rivers. In addition to finding the feed, other activities Sarmi and Inge did on the ground was walking and resting on the ground floor. Trees that are high in nutrient content are mostly located in the middle and upper forest strata (Grundmann 2006). Activities of Sarmi and Inge are almost resembling those as wild orangutans, i.e., by moving at altitudes of $>10 \mathrm{~m}$ (Kanamori et al. 2010), and they were rarely found in the height of $<5 \mathrm{~m}$.

Most orangutans are moving, feeding, and resting in the trees. Orangutans move by brachiation, bipedal, quadrupedal, and climbing. The ability to move and move over the canopy is essential to finding and obtaining feeding locations (Grundmann 2006). When orangutans move on trees, they can also avoid the predator threat of wild boar and leopard (Kanamori et al. 2012; Jule et al. 2008) and avoid soil bacteria and parasites (Grundmann et al. 2006).
Table 4. The result of Mann Whitney test in strata used of the orangutan in Kehje Sewen forest, East Kalimantan, Indonesia

\begin{tabular}{|c|c|c|c|c|}
\hline $\begin{array}{l}\text { Indi- } \\
\text { vidual }\end{array}$ & (0 m) & $(<5 \mathrm{~m})$ & $(5-10 \mathrm{~m})$ & $(>10 \mathrm{~m})$ \\
\hline $\begin{array}{l}\text { Siwi } \\
\text { Sarmi }\end{array}$ & \multicolumn{4}{|c|}{ 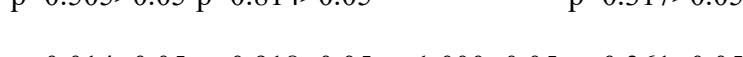 } \\
\hline $\begin{array}{l}\text { Mona } \\
\text { Inge }\end{array}$ & \multicolumn{4}{|c|}{$\mathrm{p}=0.014<0.05 \mathrm{p}=0.918>0.05 \mathrm{p}=1.000>0.05 \mathrm{p}=0.361>0.05$} \\
\hline
\end{tabular}

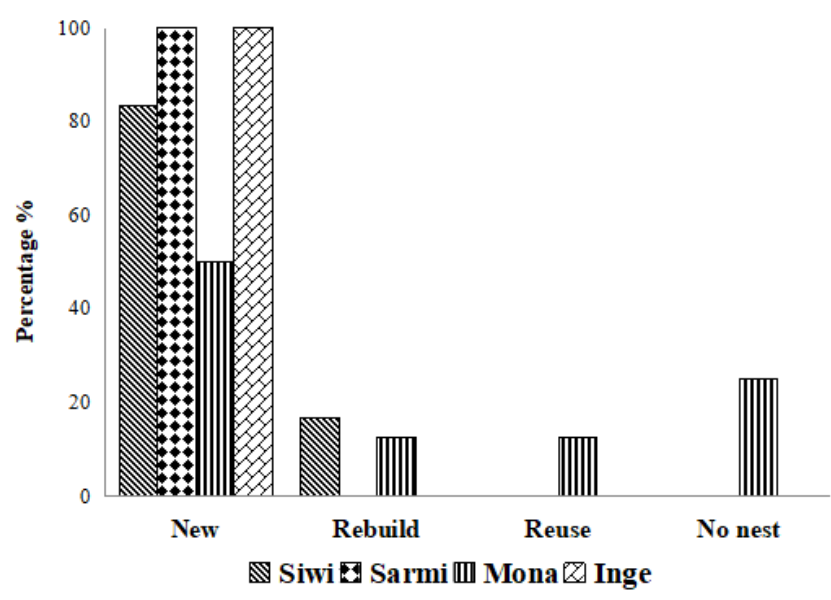

Figure 4. The proportion of nesting of the orangutan in Kehje Sewen forest, East Kalimantan, Indonesia $\square$

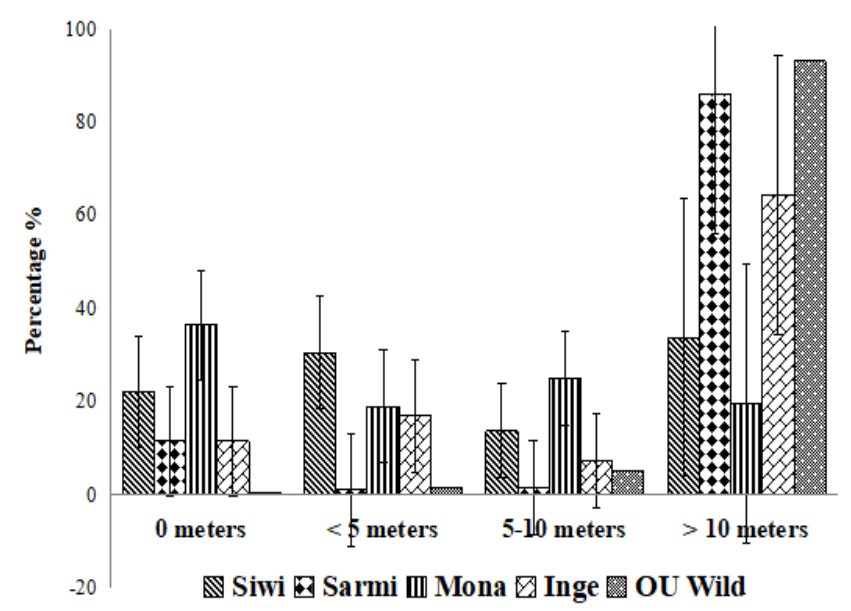

Figure 5. The proportion of height used orangutan in Kehje Sewen forest, East Kalimantan, Indonesia $\square$ 


\section{Home ranges}

Home range is another parameter used to determine the success of adaptation. The home range of reintroduction orangutans in Kehje Sewen forest is presented in Figure 6. After one year from the release, Inge had the most extensive home range, followed by Siwi, Sarmi, and Mona in that order. Mona was doing a limited activity, only exploring the surroundings of the release place. Meanwhile, Siwi was more active exploring than other orangutan individuals. Mona and Siwi rarely visited feeding trees to eat and were only occasionally observed resting and exploring. Siwi moved more frequently and spent more time on the ground, making her range wider compared to that of other orangutan individuals.

In addition, the ranges of Inge and Siwi were crisscross and overlap. This is supported by observations of Inge and Siwi visited feeding trees to eat and traveling together. Within overlapping roaming areas, there will usually be competition in defending their respective domains. Competition between individual female orangutans in dietary needs is influenced by different ecological pressures and leads to the formation of dominance (Singleton and van Schaik 2000). The home ranges of Sarmi and Mona did not overlap, and they utilized very little of the available area. $\square$
Exploration by orangutans is a strategy to find food and for their survival, while the routine exploration within a specific time will form the extent of the roaming area. Orangutans will maintain their home range because the area has a stable source of feed productivity or for the benefit of reproduction (Singleton et al. 2009). Sarmi was found actively visiting the feeding tree located near the Camp, away from the place where they were initially released. During September 2014, fruit and orangutan season were more commonly found near Camp for feeding and other social interactions. Orangutans chose and maintained their home range in a particular habitat for the reason that the habitat was more abundant in feed and also for reproductive interest (Singleton et al. 2009).

\section{Discussions}

The method of release of BOSF (Borneo Orangutan Survival Foundation) is a hard release, which means that the orangutans were released directly at the release site without any food support. This kind of release method requires orangutans to adapt to the new existing environment directly. The orangutans endured the new environment by utilizing natural foods in the forest. The HardBOS method was selected by BOSF because the orangutan individuals had already gone through the forest school program.

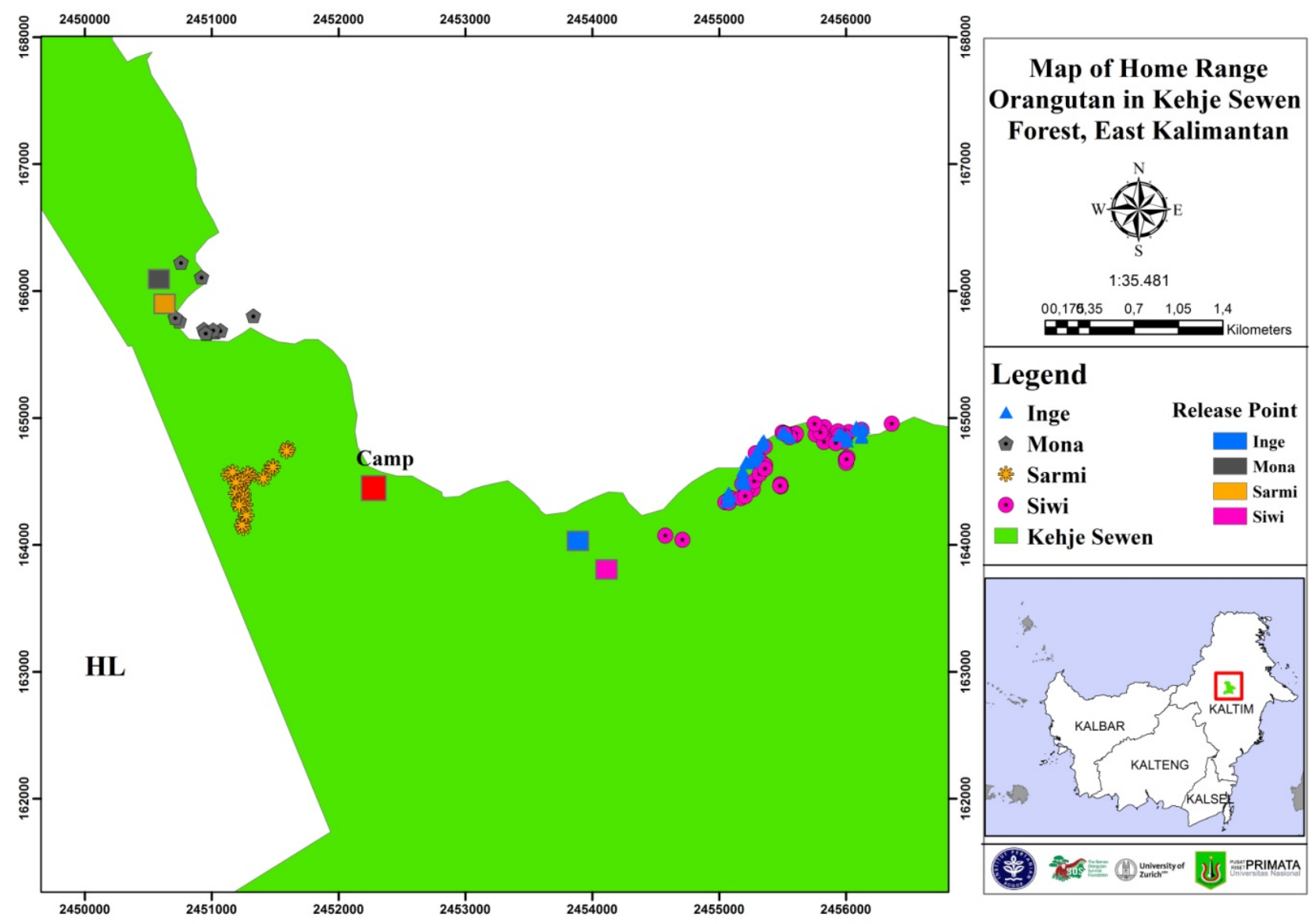

Figure 6. Map of home range orangutan in Kehje Sewen forest, East Kalimantan, Indonesia 
Orangutan Individuals Sarmi (19 years) and Siwi (15 years) are semi-wild orangutans placed on the island. After one year of release, Sarmi behaved similarly to those of the wild orangutans in the Danum Valley. Siwi, on the other hand, spent more time resting. Individuals of semi-wild orangutans who have undergone a final rehabilitation process on the island had better adaptation capability than those coming from cages. This is because the orangutans on the island have already familiar with skills in living with vegetation and enrichment in the artificial forest. Alternatively, this would have happened because the island is 2 ha area size and supported with food twice a day. Siwi must share a space on the island with three other orangutans, while Sarmi also shared space with five other orangutans for four years. Thus they should be accustomed to living on the island by utilizing the existing vegetation. $\square$

Orangutan Individuals Inge (15 years) and Mona (20 years old) who have an ex-rehab background after four years of forest school, returned to the cage for seven years before being released. After one year of release, Inge behaved similarly to those of the wild orangutans in the Danum Valley. The survival learning in the forest that was acquired through forest schools can be seen in rehabilitated orangutans by their use of natural foods present in forest and nest-making skills. This is a result of the adaptation of good behavior to individual rehabilitants orangutans (exrehab) to successfully survive in the forest. Meanwhile, Mona spent more time resting as compared to wild orangutans. The survival learning in forests through forest schools was not understood and applied by Mona, as that she spent more time resting and not making nests.

After one year from their release, only two of the four female orangutans (Sarmi and Inge) spent more of their time at the height of $>10 \mathrm{~m}$. Meanwhile, Mona spent more time on the ground looking for pits and insects (ants, termites). In addition to finding food, they often did other activities such as walking and resting on the ground.

Another parameter for determining the success of adaptation is the ability to move on the tree, in addition to their ability to climb into the center of the tree canopy and move freely (Ashbury et al. 2015). The climbing height of orangutans is influenced by the presence of food sources and the ability to competently perform their activity on the tree. Orangutans were often seen to spend time at a certain height for comfort and reduce to fear (Grundmann 2006).

This study shows a pattern of adaptation after a year of almost equal release between orangutans from the island and orangutans from cages. Sarmi individuals (semi-wild, island) and Inge (ex-captive, cages) behaved practically similar to the wild orangutans in the Danum Valley. Whereas Siwi (semi-wild, island) and Mona (ex-captive, cage) had higher resting behavior than wild orangutans. Moving behavior of all individual orangutans was almost similar to that of the wild orangutans.

After one year, the released orangutans were able to adapt well and to survive in the forest depending on the background and ability of each individual orangutan. Each orangutan has different levels of intelligence as well as the ability to understand survival learning in the forest.
Although the final stages of rehabilitation are the same, the results will be different. Inge's (ex-captive, cage) behaviors were consistent in learning, so she could adapt well, as indicated by her patterns of activity and other supporting behaviors that already resembled those of the wild orangutans. Siwi (semi-wild, island) was also able to adapt well, especially with the high time spent for resting. Rehabilitant orangutans who can learn well in the forest life may not leave human ways as well; they became proficient in both ways of life (Russon and Galdikas 1995; Snaith 1999).

In conclusion, there was a high similarity of diet of the released orangutans and the wild orangutans, but there were still differences in daily activity patterns, strata use, and nesting behavior among individuals in each category (semi-wild / ex-captive, island/cage), and the adaptability is more influenced by each individual capability, rather than the final stage of rehabilitation (island vs. cage). However, as the number of individuals per category was minimal (only two individuals per category), this conclusion cannot be generalized.

\section{ACKNOWLEDGEMENTS}

We thank Yayasan Penyelamat Orangutan Borneo (BOSF: Borneo Orangutan Survival Foundation), Pusat Rehabilitasi Orangutan Kalimantan Timur - Samboja Lestari (PROKT-SL) and PT. RHOI (Restorasi Habitat Orangutan Indonesia), BKSDA Kalimantan Timur and Muara Wahau people who have given the support for conducted research in Kehje Sewen Forest. We also thank all assistance of PT. RHOI during the study. SNB is very grateful to Arcus Foundation and Department of Anthropology of Zurich University for support funding.

\section{REFERENCES}

Altmann J. 1974. Observational study of behaviour: sampling methods. Behaviour 49 (3/4): 227-267.

Ashbury AM, Posa MRC, Dunkel LP, Spillmann B, Atmoko SSU, van Schaik CP, van Noordwijk MA. 2015. Why do orangutans leave the trees? Terrestrial behavior among wild Bornean orangutans (Pongo pygmaeus wurmbii) at Tuanan, Central Kalimantan. Am J Primatol 77 (11): 1216-1229.

Baker LR. 2002. Guidelines for nonhuman primate re-introductions. Newsletter of the Re-introduction Specialist Group of the IUCN's Species Survival Commission (SSC), 21.

Beck B, Walkup K, Rodrigues M, Unwin S, Travis D, Stoinski T. 2007. Best practice guidelines for the re-introduction of great apes. The World Conservation Union (IUCN), Gland, Switzerland.

Delgado RA, van Schaik CP. 2000. The behavioral ecology and conservation of the orangutan (Pongo pygmaeus): A tale of two islands. Evol Anthropol. 9: 201-218.

Groves CP. 2001. Primate Taxonomy. Smithsonian Institution Press, Washington DC.

Grundmann E. 2006. Back to the wild: will reintroduction and rehabilitation help the long-term conservation of orangutans in Indonesia. Soc Sci Inform 45 (2): 265-284.

Jule KR, Leaver LA, Lea EG. 2008. The effects of captive experience on reintroduction survival in carnivores: A review and analysis. Biol Conserv 141: 355-363. $\square$ 
Kanamori T, Kuze N, Bernard H, Malim TP, Kohshima S. 2010. Feeding ecology of Borneo orangutans (Pongo pygmaeus morio) in Danum Valley, Sabah, Malaysia: A 3-year record including two mast fruitings. Am J Primatol 72: 820-840.

Morrogh-Bernard H, Husson S, McLardy C. 2002. Orang-Utan Data Collection Standarization. Orang-Utan Culture Workshop, February 2002. San Anselmo, USA.

Morrogh-Bernard HC, Husson SJ, Knott CD, Wich SA, van Schaik CP, van Noordwijk MA, Lackman-Ancrenaz I, Marshall AJ, Kanamori T, Kuze N, Sakong RB. 2009. Orangutan activity budgets and diet. In: Wich SA, Atmoko SSU, Setia TM, van Schaik CP. (eds.). Orangutans: Geographic Variation in Behavioral Ecology and Conservation. Oxford University Press, New York.

Nater A, Maja P. Mattle-Greminger, Nurcahyo A, Nowak MG, Manuel M, Desai T, Groves C, Pybus M, Sonay TB, et al. 2017. Morphometric, Behavioral, and Genomic Evidence for a New Orangutan Species. Curr Biol 27 (22): 3487-3498.

Prasetyo D, Morrogh-Bernard HC, Wich SA, van Schaik CP, Atmoko SSU, Ancrenaz M. 2009. Nest building in orangutan. In: Wich SA, Atmoko SSU, Setia TM, van Schaik CP. (eds.). Orangutans: Geographic Variation in Behavioral Ecology and Conservation. Oxford University Press, New York.

Russon AE, Galdikas BMF. 1995. Constraints on great ape imitation: Model and action selectivity in rehabilitant orangutans (Pongo pygmaeus). J Compar Psychol 109: 5-17.

Russon AE, Handayani DP, Kuncoro P, Ferisa A. 2007. Orangutan leafcarrying for nest-building: Toward unraveling cultural processes. Anim Cogn 10: 189-202.

Russon AE. 2002. Return of the native: Cognition and site-specific expertise in orangutan rehabilitation. Intl J Primatol 23 (3): 461-478

Russon AE. 2006. Acquisition of complex foraging skills in juvenile and adolescent orangutan (Pongo pygmaeus). Aquat Mammal 32 (4): 500510.

Russon A. 2009. Orangutan rehabilitation and reintroduction. In Wich SA Atmoko SSU, Setia TM, van Schaik CP, editor. Orangutans:
Geographic variation in behavioral ecology and conservation. Oxford University Press, New York.

Singleton I, Knott CD, Morrogh-Bernard HC, Wich SA, van Schaik CP. 2009. Ranging behavior orangutan females and social organization. In: Wich SA, Atmoko SSU, Setia TM, van Schaik CP. (eds.). Orangutans: Geographic Variation in Behavioral Ecology and Conservation. Oxford University Press, New York.

Singleton I, van Schaik CP. 2001. Orangutan home range size and its determinants in Sumatran swamp forest. Intl J Primatol 22: 877-911. $\square$

Snaith T. 1999. The behavior of free-ranging ex-captive orangutans in Tanjung Puting National Park, Indonesia. [Thesis]. University of Calgary, Calgary, Canada.

Soehartono T, Susilo HD, Andayani N, Atmoko SSU, Sihite J, Saleh C, Sutrisno A. 2007. Strategi dan rencana aksi konservasi orangutan indonesia 2007-2017. Direktorat Jenderal Perlindungan Hutan dan Konservasi Alam, Departemen kehutanan Republik Indonesia, Jakarta. [Indonesian]

Utami SS, Wich SA, Sterck EHM, van Hooff JARAM. 1997. Food competition between wild orangutans in large fig trees. Intl J Primatol 18 (6): 909-927.

Utami-Atmoko SS, Singleton I, van Noordwijk MA, et al. 2009. Malemale relationships in orangutans. 2009. In: Wich SA, Atmoko SSU, Setia TM, van Schaik CP. (eds.). Orangutans: Geographic Variation in Behavioral Ecology and Conservation. Oxford University Press, New York.

van Noordwijk MA, Arora N, Willems EP, et al. 2012. Female philopatry and its social benefits among Bornean orangutans. Behav Ecol Soc Biol 31: 247-264.

van Schaik CP. 2006. Di antara Orangutan (Kera merah). Yayasan Penyelamatan Orangutan Borneo, Bogor. [Indonesian]

van Schaik CP, van Noordwijk MA. 2003. Standardized Field Methods. http://www.aim.uzh.ch/research/orangutannetwork/sfm.html.

Yeager CP. 1997. Orangutan rehabilitation in Tanjung Puting national park. Biol Conserv. 11 (3): 802-805 